\title{
Public-Private Partnership In Indonesian Urban Water Sanitation And Hygiene Program: Human Resource Capacity's Innovation
}

\author{
Nida Hanin Dary ${ }^{1}$, Ismi Dwi Astuti Nurhaeni' ${ }^{2}$, Didik G. Suharto ${ }^{3}$ \\ ${ }^{1}$ Masters Program in Public Administration Department, Faculty of Social and Political Sciences, Universitas \\ Sebelas Maret (Email: nidahanin@gmail.com), ${ }^{2}$ Department of Public Administration, Faculty of Social and \\ Political Sciences, Universitas Sebelas Maret, ${ }^{3}$ Department of Public Administration, Faculty of Social and \\ Political Sciences, Universitas Sebelas Maret
}

\begin{abstract}
Public-Private Partnerships (PPPs) in Indonesia still face constraints on the limited capacity of human resources. Indonesian PPP with the United States Agency for International Development (USAID) in the implementation of the Indonesian Water, Sanitation and Hygiene (IUWASH) program tries to improve Indonesian sanitation which in the lowest rank in ASEAN. However, the implementation is still facing problems because human resources in local governments in Indonesia have not been able to increase their capacity so that program assistance to the government has not been able to run optimally. Therefore, human resources in Indonesia are required to be improved to be internationally competitive and innovatively synchronized with the developing technology so that human resources in Indonesia can support sustainable development. This research seeks to provide innovation in the human resource management capacity to improve the performance of local government resources on PPP in IUWASH programs in Indonesia in the face of the 4.0 Industrial Revolution. This research was conducted with literature review methods. Efforts to increase human resource capacity are carried out by creating human resource strategic planning based on analysis of the situation and potential of human resources with international standardization in training and development.
\end{abstract}

\section{Keywords:}

human resources management; IUWASH; Public Private Partnership, sound governance

\section{Introduction}

Indonesia is the country with the second worst level of sanitation in ASEAN. This has made the Indonesian Government moved to work with the United States aid agency United States Agency for International Development (USAID) to develop sanitation projects in several regions in Indonesia (USAID, 2017). This collaboration is carried out by the government in the system of Government Cooperation with Business Entities (KPBU). Government cooperation with business entities (PPP) includes contractual agreements, partnerships, and collaborative activities used in policy development, program support and delivery of government programs, and services (Chien, 2016). To improve public services in quality and effectiveness and to improve operations, Government Collaboration with 
Business Entities (KPBU) emerged as a strategic instrument driven by joint public and private service providers and gathered complete knowledge, capabilities and resources over a long period ( Keers, 2018). Government Cooperation with Business Entities (KPBU) has an important role in implementing a development strategy in a country because the partnership between the government and the private sector provides an answer to the lack of human resources in implementing government development programs as well as being a solution to the problem of state finances in development (Adnan, 2013). At present, the old paradigm for countries that compete with one another and compete to defeat each other has shifted to the era of collaboration. The state cannot run alone to achieve its country's goals effectively and efficiently. Thus, the government will collaborate well with the private sector and even with neighboring countries to achieve effective development progress. This collaboration is supported by globalization that is happening now which facilitates cooperation between the Government and Business Entity (KPBU) between countries and regions. Collaborative activities in the global era have an impact on the high demands of organizational performance where the implementing organizations of Government Cooperation with Business Entities (KPBU) must be able to keep pace with the pace of development occurring on the international scene.

Government collaboration with business entities (PPP) introduces work arrangements based on long-term mutual commitment between public sector organizations and organizations outside the public sector (Bovaird, 2004). The role of employees is greatly influenced by the increased collaboration carried out by their organizations. Neither with the cooperation between the government and the private sector must be supported by adequate human resources. However, the implementation of the Government Cooperation with Business Entities (KPBU) has not been maximally applied to the process of collaboration between the Government of Indonesia and USAID in the sanitation improvement and development project in Indonesia.

This collaboration was carried out in the Indonesia Urban Water, Sanitation and Hygiene (IUWASH) project. Limited funds from local governments to be able to improve sanitation at many points in their regions are made by the Government Cooperation with Business Entities (PPP). Domestic wastewater management has not been a focus for many City / Regency Governments. Therefore conditions for this sector are generally still low, 
while physical development to develop the sanitation sector, if any, is not optimal. This can be seen from the lack of budget allocation in the APBD (City / Regency Government Budget) (Valešová, et al., 2017). The limited availability of municipal wastewater management services provided by the Regional Government has led to high levels of contamination of groundwater and surface water sources.

Indonesia because the existence of new autonomous regions is not accompanied by adequate human and financial capacity. Other obstacles experienced by the Government Cooperation with Business Entities (KPBU) in Indonesia are 1) the adequacy of project financing from investors and banks; 2) guarantee problems; 3) fulfillment of financing requirements; 4) land acquisition; up to 5) institutional capacity and cooperation (Rifai, 2016). Thus many delays occur in development, especially infrastructure development. On the other hand, there are still available human resources who have the skills to support the effectiveness of the performance of Government Cooperation with Business Entities (PPP). It's just that the human resources owned by each local government are not maximized with proper management. While the regional development planning process needs to be balanced with the availability of the quality of regional apparatuses and resources, both human resources and funding sources, so that the quality of human resources can be guaranteed to support the effectiveness of achieving development goals. The need for performance measurement is used as a basis for evaluating performance, namely to assess the success or failure of an organization, program or activity (Riawan, 2016).

The Indonesian Government's collaboration with the United States Agency for International Development (USAID) in a Public Private Partnership (PPP) project on sanitation management and clean water management IUWASH has completed its first period of contact in 2010 to 2016 . However, both parties agreed to extend the contract until the second agreed period and was carried out in 2017 until 2021 (USAID, 2019). The performance of IUWASH which carries about the four pillars of behavior, clean water, sanitation, and finance, to be improved in the course of the project's progress has yielded tangible results (USAID, 2017). This is indicated by an increase in the approach that has been made to the community so that people can change their bad habits in water management in their community life. The Indonesia Urban Water, Sanitation and Hygiene (IUWASH) program is felt to have been able to provide significant changes in the community. However, 
the goal of IUWASH is to focus on two important points namely community empowerment and government assistance.

Government assistance itself needs to be done by IUWASH where the United State Agency for International Development (USAID) also contributes to the transfer of technology, teaching and transfer of education to the Government of Indonesia (USAID, 2016). This is done so that the government can then support the behavior of the people who have begun to organize in the management of clean water. In addition, assistance from the United States Agency for International Development (USAID) in the Indonesia Urban Water, Sanitation and Hygiene (IUWASH) program must also be provided through mentoring PDAM performance in handling sanitation improvements in regions in Indonesia. Assistance for Bappeda was also carried out to be able to support the performance of the Indonesia Urban Water, Sanitation and Hygiene (IUWASH) program to the maximum and effectively (USAID, 2019). However, the assistance provided to the government is still considered to be less than optimal. This is related to the still low performance produced by the Government of Indonesia in the Indonesia Urban Water, Sanitation and Hygiene (IUWASH) program. This is of course directly related to the capacity of the existing human resources in the Regional Government agencies in Indonesia where they have not reached sufficient capacity to be able to maximize the performance of the Indonesia Urban Water, Sanitation and Hygiene (IUWASH) program. Several factors will be examined to be able to classify the inadequacy of human resource management in Local Governments in Indonesia related to the IUWASH program. Afterwards, the increase in innovation will be analyzed to be able to increase the capacity of human resources in the Local Government in Indonesia to support the Indonesia Urban Water, Sanitation and Hygiene (IUWASH) program.

This study seeks to answer the question of how to increase innovation in human resource management to improve the performance of local government resources in the Government Cooperation with Business Entities (KPBU) of the Indonesian Urban Water, Sanitation and Hygiene (IUWASH) program in Indonesia in the challenge of the Industrial Revolution 4.0. To answer the question above, the writer will use the paradigm of sound governance. Sound governance is offered as an alternative to good governance because it is more comprehensive and includes the strength of global or international governance 
(Farazmand, 2012). With this paradigm, it can be analyzed the development of human resource management in the era of globalization that is right to improve the performance of employees in the sector of Government Cooperation with Business Entities (PPP). This research was conducted with a descriptive qualitative research method using literature studies with data collection techniques from several previous literatures which were analyzed to represent different points of view.

\section{Methods}

This research was conducted with a literature study method from a book on human resource management learning, journals and articles on previous research on IUWASH, the United State Agency for International Development (USAID), Government Cooperation with Business Entities (PPP), sound governance, and human resource management, as well as news that is adapted from websites related to IUWASH, USAID, PPP and human resource management. Data is collected from journal articles, country reports and previous research. Then the data that has been collected is processed with the theory of human resource management and sound governance. Thus generating new data about the needs of research subjects which are then analyzed again to design strategic planning as a form of innovative solutions to the sustainable development of local government human resource management in PPP in Indonesia in the challenge of the Industrial Revolution 4.0.

Through literature studies from several international journals that have been selected in accordance with the theories and concepts needed as well as data from existing cases about IUWASH in several regions in Indonesia, we will get a classification and the detailed context of the background of not running good human resource management in the Regional Governments in Indonesia especially in the implementation of the IUWASH program. After getting the context of human resource management needed, then the data will be processed again with the theory of human resource management and its implementation in the field of government. The capacity that cannot be increased, of course, is related to the competencies that exist in each individual human resource. Sharpening the analysis on work motivation and commitment of human resources in local governments in Indonesia was carried out in this study. This is related to the transfer of technology and knowledge transfer conducted by the United States Agency for International Development 
(USAID) to improve the performance of the Indonesia Urban Water, Sanitation and Hygiene (IUWASH) program. Developments in the Industrial Revolution 4.0 greatly influenced the faltering motivation and commitment of human resources in Local Governments faced with the progress of globalization and increasing the level of work methods that need to catch up with the pace of standardizing international performance. Thus it can be seen the needs of human resources in local governments in Indonesia in the implementation of the Indonesia Urban Water, Sanitation and Hygiene (IUWASH) program. The values of motivation and commitment become materials which are then processed to find innovations in increasing human resource capacity in Local Governments in Indonesia, especially related to the IUWASH program. So that innovation can be obtained to improve human resource management to increase the capacity of civil servants in Local Governments in Indonesia to support the implementation of the Government of Indonesia Cooperation with Business Units (PPP) project with the United State Agency for International Development (USAID) in the Indonesia Urban Water, Sanitation program, and Hygiene (IUWASH). This innovation will then be a solution offered by the author in the development of sustainable human resource management.

\section{Results and Discussion}

Several studies on Public Private Partnerships (PPP) have been conducted, including Chien (2016) which discusses the quality of social interaction in public-private joint programs affecting the flow of knowledge and the dynamics of organizational learning and trying to evaluate the potential impact of human resource management in Public Private Partnerships (PPP) in learning organizations in the Taiwan public sector. The study explained that there is a fundamental difference between public and private organizations, and about the existence of conventional policies in a private company to have a greater percentage of human resources which internally trained through strategies that make them as part of branding efforts, while the public sector requires integration of 'make and buy' to maintain and continue to improve the status quo (Chien, 2016).

In addition, Keers (2017) discusses the exploration of risk awareness and risk management practices that support the establishment of maintenance partnerships through multiple case studies of two projects of Public Private Partnerships (PPP) and short industry 
surveys. Kessey (2017) conducted a study to examine the dynamics of change and analysis of the success of the Business Process Re-Engineering method in the application of Public Private Partnerships (PPP). In this study, it was stated that public sector organizations are faced with restrictions to adopt change. Public organizational culture is more rigid, more structured, and more regulated by laws and regulations, making it difficult to transfer Business Process Re-Engineering applications and strive for success between the public and private sectors in the successful delivery of effective and cost-effective Public Private Partnerships (PPP) projects (Kessey, 2017).

Research from Qustolani (2017) identifies employee performance that affects the rate of Public Private Partnerships (PPP) in the era of globalization. The effect of job satisfaction, procedural justice and compensation on employee performance, both partially and simultaneously has a positive and significant influence (Qustolani, 2017). The quality of human resources also has a significant positive effect on regional financial performance and to improve regional financial performance can be done by improving the quality of human resources, with the most important factor determining the experience (Riawan, 2016). Ahmad, et al. (2014) examined the moderate influence of ASEAN free trade agreement between total quality management and business performance. In his research, it was explained that ASEAN trade liberation through the elimination of intraregional tariffs contributed to increased manufacturing in ASEAN countries to be more efficient and competitive in the world market with an ASEAN Free Trade Agreement (AFTA) that is good for foreign companies because they have competitive advantages, however AFTA so profitable for local companies (Ahmad, Zakuan, Jusoh, Yusof, \& Takala, 2014). This is also a reference to the importance of Public Private Partnerships (PPP) in this era of globalization. Especially for Indonesia in the progress of AFTA free trade. Companies that want to compete in the global market must improve the effectiveness of their total quality management (TQM) on business performance because the quality environment is an important factor to survive in the competitiveness of global market (Ahmad, Zakuan, Jusoh, Yusof, \& Takala, 2014).

The influence of motivation, work discipline, and work environment on employee performance examined by Selvia (2014) concluded that the existence of good and comfortable motivation and environmental influences had a positive influence on employee 
performance. Higher work discipline is also an indication of the increase in employee performance (Selvia, 2014). These indicators are used in this study as assessments that must be considered in human resource management to improve the effectiveness of Public Private Partnerships (PPP) performance in the era of globalization (Selvia, 2014). The study of improving employee performance through motivation, discipline, work environment, and commitment is also presented in Prihantoro's research (2012). The existence of a positive influence of motivation in sincerity in completing work and the courage to sacrifice, responsibility in work, honest and consistent in work, and commitment shows that the higher motivation, then the commitment of human resources will increase (Prihantoro, 2012). Elements of human resource development such as recruitment, training, career development, benefits, promotion, transfer, structural and technical special training also have an influence on employee performance to create work effectiveness, especially compensation, promotion, technical training and structural training that become factors in improving the performance of human resources (Kalangi, 2015). Nevertheless, human resource management in Indonesia has enormous challenges such as cultural change and efficiency which are the main challenges of human resource management in the civil and private sectors, while talent seekers are seen as a major challenge for the service industry (Bennington \& Habir, 2003).

Human resources management in Asia-Pacific involves a combination of forces related to globalization, competition, the struggle for talent, recognition of the need for change by organizations and decision makers, and evidence of successful best practices, which also contribute to changes towards directed equality in Asia-Pacific (Budhwar, Varmab, \& Patel, 2016). The strengthening of ASEAN ties with the realization of the AFTA and the ASEAN Economic Community (AEC), has become an important point that must be considered as a challenge for human resource management in ASEAN countries. This is because with the advent of the AEC, workers or employees must be prepared to be able to balance the pace of growth and development across borders with other AEC participating countries. The AEC which has been put into effect by ASEAN countries has shown a strong commitment to its development. From the perspective of management talent of human resource, the prospect of free movement of labor is very interesting to apply in this era of globalization, but the application of free labor movements will also be very challenging with 
the existence of significant differences in government and cultural diversity in ASEAN countries member (Chen \& Su-Yen, 2016).

Facing the challenges of the AEC, Indonesia needs to prepare all managerial aspects of human resources, especially at the Public Private Partnerships (PPP) so that they are ready to go in line and be comparable or even better than other ASEAN countries. In this case, an analysis of the sound governance paradigm is needed to understand the influence of globalization such as the AEC free market on the effectiveness of Public Private Partnerships (PPP) performance. Farazmand (2012) explained that sound governance is offered as an alternative to good governance because it is more comprehensive than other concepts, including the important strength of global or international governance, including normative and technical and rational features of good governance, presenting a balanced view of governance that is lacking bias and consider the original features of the customary governance system, have all the characteristics of the quality of better governance of good governance technically, professionally, organizationally, politically, democratically, and economically, capacity, anticipatory behavior, democratic character, responsiveness and competencies, and cultural values embedded in the values and structure of society, as well as sound governance in accordance with constitutional values and responsive to international norms, rules and regimes (Farazmand, 2012).

Handling of the Indonesia Urban Water, Sanitation and Hygiene (IUWASH) program implemented by the Indonesian government with the United State Agency for International Development (USAID). It can also be compared with the handling of health services that are also carried out between the Government of Indonesia and the United State Agency for International Development (USAID). Eichler (2018) explained in his journal that discussed implementation research to improve health services and financial reform in universal health insurance in Indonesia. In this study discussed the performance of health service improvement programs carried out in collaboration with the Government of Indonesia with the United States Agency for International Development (USAID) by conducting joint health insurance (Eichler, 2018). The research put forward an analysis of the implementation of the program's performance in helping to build the strength of health services, as well as its financial department, especially in order to monitor the health service process carried out in connection with the program. This review is important for this 
research to be able to see the performance of the United States Agency for International Development (USAID) previously in conducting Government Cooperation with Business Entities (KPBU) with the Government of Indonesia. In order to get a more specific view of the implementation model and the bias found the same obstacles that might be faced as in the IUWASH program.

Indonesia, which is affiliated with ASEAN, is also moving its people towards the ASEAN Economic Community. Not only promoted by society at large, the direction of the business sector, economy, and development in Indonesia is also prepared to compete in the international arena. Indonesia which is included in ASEAN has moved its people towards the ASEAN Economic Community. Not only being widely promoted in the community, the direction of the Indonesian business and economic sector was also carried out to be ready to compete in the free trade of the international market. Public Private Partnerships (PPP) that move the public and private sectors in the development and improvement of projects in Indonesia also begin to lead to international cooperation. Both the collaboration of technology transfer, education and human resources. But the performance of employees in Public Private Partnerships (PPP) in Indonesia cannot be said to be effective in the development of globalization. This is indicated by the existence of new autonomous regions that are not accompanied by adequate human resources and financial capacity as well as the problem of guarantee and fulfillment of financing requirements, and institutional capacity and inadequate cooperation (Rifai, 2016). While the index of human resource development based on skills in Indonesia was recorded in the Human Development Reports by the United Nation Development Program (UNDP) of 40.8\% of talented employees (UNDP, 2018). While developing countries in Southeast Asia such as Thailand (37.4\%), Philippines (30.6\%), Laos (33.2\%), Vietnam (32.8\%), Myanmar (17.7\%), and Cambodia $(9.7 \%)$ is still below the index value of employees who have skills in Indonesia. Nevertheless, Indonesia still has to compete with other Southeast Asian countries which have an index of employees who have high skills far above Indonesia such as, Malaysia (67.3), Brunei Darussalam $(79.1 \%)$, and Singapore (81.7\%) (UNDP, 2018). This figure shows a huge capacity of human resources in Indonesia who have the skills to be able to work optimally and effectively from both the public and private sectors. So that Public Private Partnerships (PPP) should run 
well, considering that Indonesia has an index of human resource development based on fairly high skills.

Problems arise when human resources with skills are not the main obstacle to the effectiveness of Public Private Partnerships (PPP) performance, but rather how human resources with qualified skills can be arranged in such a way that the effectiveness of performance in the realm of globalization can be created. The challenges of human resource management in Indonesia in the face of globalization and internationalization are increasing considering ASEAN countries are now competing to become increasingly flexible and dynamic with global developments, especially in neighboring countries. ASEAN countries learn from each other about the movement and development of neighboring countries, so that they can prepare themselves to collaborate in international partnerships.

Human resource management in Indonesia is an important figure in maintaining the work effectiveness of Public Private Partnerships (PPP) employees by empowering skilled staff resources to be ready to face the evolving dynamics in the Public Private Partnerships (PPP) era of globalization. The management provided includes motivation in sincerity in completing work, responsibility in work, honest and consistent in work, and commitment (Prihantoro, 2012). Elements of human resource development such as recruitment, training, career development, benefits, promotion, transfer, structural and technical special training also have an influence on employee performance to create work effectiveness, especially compensation, promotion, technical training and structural training that become factors in improving the performance of human resources (Kalangi, 2015). Performance improvement is needed to support the effectiveness of performance in achieving the objectives of the collaboration between Indonesian Public Private Partnerships (PPP) and foreign countries.

Effective human resource management is needed in Public Private Partnerships (PPP) to achieve more effective collaboration, to prevent overlapping and duplicated services, to achieve more efficient performance and encourage innovation, to save costs, to effectively manage and communicate change, and to involve employees through effective consultation (Yahiaoui, Anser, \& Lahouel, 2015). Collaboration between the public and private sectors, both those that operate in the country and those that cooperate with other countries, will be effective with the effective performance of human resources. Work effectiveness can be achieved by increasing motivation and work commitment (Senyucel, 2009). Work 
motivation is needed by employees to encourage responsiveness and desire to continue to compete in their jobs. Motivation is also very important considering the encouragement of collaboration between countries is increasingly strengthened so that the willingness and ability to continue to learn and develop for employees must continue to be improved. With work motivation, Public Private Partnerships (PPP) employees can be easily encouraged to develop and innovate towards the advances in technology, information and knowledge needed by Public Private Partnerships (PPP) in the implementation of independent work projects and cooperation that use knowledge and technology transfer with foreign parties. The motivation component consists of 3 things, that is, ignition where someone will have the initiative or desire to achieve a goal, direction that is the action that someone takes in achieving their goals, and the last is maintenance or maintenance of the person's behavior until the goal is achieved (Senyucel, 2009). These three things should be emphasized by human resource managers in Public Private Partnerships (PPP) in Indonesia to ignite the work motivation of employees to support the effectiveness of Public Private Partnerships (PPP) cooperation in Indonesia in the collaboration sector and competition in the international free market. With work motivation, the skills possessed by employees can be delivered effectively and develop in harmony with the goals of the organization.

Commitment is also an important factor in improving work efficiency and should be an important concern for human resource managers in the Public Private Partnerships (PPP) sector in Indonesia in the face of the era of globalization. The commitment of employees can be obtained by means of human resource managers regulating the organizational climate in it so that the work atmosphere is created with good and conducive conditions so that it can bring its employees to high work commitments (Senyucel, 2009). In facing the era of globalization that is very dynamic, flexible, and volatile, employee commitment is needed to encourage learning skills and develop along with international dynamics that will rub against organizational actions in Public Private Partnerships (PPP). The pressure that arises because of the collaboration carried out by Public Private Partnerships (PPP) with Multi National Corpotation (MNC) and with other governments will be even greater compared to the pressure placed on employees of companies or organizations that only move within the internal scope of Indonesia. The demand for performance adaptation with foreign companies is also a matter that must be faced. Thus, employee commitment needs to be 
increased to avoid employee absenteeism and turnover. Commitment is needed so that employees face pressures and demands that arise along with the absorption of globalization values at Public Private Partnerships (PPP) in Indonesia which are getting bigger and more complex, the commitment of employees in determination, willingness and loyalty in work can be maintained and increase. So that the expected effectiveness of performance can be achieved without the constraints of pressure and the meaningful demands of globalization.

Cooperation between Indonesian Public Private Partnerships (PPP) in ASEAN and other countries is increasingly prevalent in various sectors. Indonesia also participated in the collaboration to develop the ASEAN-Japan 10-Year Strategic Economic Cooperation Roadmap which aims to achieve the target of doubling trade and investment between ASEAN and Japan in 2022 (Indonesian Ministry of Foreign Affairs, 2015). The transportation infrastructure projects between the ASEAN-Republic of Korea (RoK) Transport Cooperation Forum and the Indonesia-Korea Transport Cooperation Meeting include Transit Oriented Development in Jabodetabek, Jakarta Phase 2 Light Rail Transit, Hang Nadim-Batam Airport, Komodo-Airport Labuan Bajo and Makassar-Pare-Pare Railroad (Dephub RI, 2018). To support this collaboration, the transfer of knowledge and technology is carried out among the countries involved. Public Private Partnerships (PPP) also accept transfer technology. Not only the public sector, but also the private sector in Indonesia must be able to organize the absorption of the technology provided quickly and precisely. Employees with good abilities are available in Indonesia, but managerial and regulation for human resources requires stronger commitment and motivation as an effective foundation for performance in facing globalization and internationalization of Public Private Partnerships (PPP). A government may be good in applying domestic managerial value, but it does not rule out the possibility that in the public sector the value system is in conflict or in opposition to foreign and global forces (Farazmand, 2013). Therefore, human resource management is very important in achieving the effectiveness of Public Private Partnerships (PPP) performance in this era of globalization.

According to the National Law Development Agency (Ministry of Law and Human Rights of the Republic of Indonesia) the obstacles that occur in implementing Public Private Partnerships (PPP) schemes in infrastructure development in Indonesia are due to the large number of parties from the state institutions involved (Supancana, 2015). The Public Private 
Partnerships (PPP) scheme that will be implemented in Indonesia is under the auspices of the National Development Planning Agency (Bappenas) so that any other institution or country that will carry out Public Private Partnerships (PPP) projects in Indonesia must go through the National Development Planning Agency (Bappenas). Other institutions that also handle the flow of Public Private Partnerships (PPP) project implementation in Indonesia are the Ministry of Finance, the Ministry of Economic Affairs Coordinating, and the Committee for the Acceleration of Priority Infrastructure Provision (KPPIP). Thus it is very necessary for the implementation of a more effective framework and efficient human resource management in handling this Public Private Partnerships (PPP) project. As explained by the National Law Development Board of the Republic of Indonesia where the agency handling Public Private Partnerships (PPP) in Indonesia has not been supported by competent human resources to support the Indonesian Public Private Partnerships (PPP) scheme, it can run to improve the implementation of infrastructure development with the help of foreign institutions or countries (Supancana, 2015). The assistance of other institutions or countries in implementing Public Private Partnerships (PPP) schemes in Indonesia will be very helpful and become one of the positive impacts of globalization. Thus, special institutions that handle the implementation of infrastructure development with Public Private Partnerships (PPP) schemes need to place quality of human resources in performance. In addition to the performance of the implementation of domestic Public Private Partnerships (PPP) scheme flows. Human resources in question must also be able to master communication and technology capital in this digitalization era, especially with regard to the relationship between Public Private Partnerships (PPP) implementers and foreign investors in more structured coordination requirements. For example in the case of PT Ilthabi Energia's MicroHydro in Aceh, a report from the National Law Development Agency states that one of the problems faced is the weak co-ordination between institutions that are considered to be very insufficient, thus hampering Public Private Partnerships (PPP) performance and causing misunderstanding (Supancana, 2015). Overlapping policies and lack of understanding of human resources that overcome them cause existing regulations not to work properly.

Strategic planning based on the analysis of the situation and the potential that exists in human resources within the institutions that regulate Public Private Partnerships (PPP) schemes in Indonesia is very necessary to increase the capacity of human resources in their 
performance on Public Private Partnerships (PPP). Strategic planning is the formation of a relationship between long-term goals, resources, and environmental conditions in an organization or company using certain methods (Bņrziņs, 2014). The planning process is complex and requires expertise to integrate the factors that are then described to be discussed, and the resulting strategic plan will set the main objectives to be chosen (SJPH, 2014). The main objectives must be focused before determining strategic planning in an organization. This makes it easier to examine the real needs of the organization to achieve its main goals on target. The strategy itself is an action plan made by senior management to achieve the desired position in a competitive environment (Senyucel, 2009). The existence of strategic planning will encourage human resources with improved management that is structured in stages of definite capacity building. The human resource management strategy can also be referred to as an open or closed agenda of an organization to regulate its employees in achieving the long-term goals and objectives of the organization (Tyson, 1995). Strategic planning is aimed at achieving Public Private Partnerships (PPP) scheme regulatory agencies in Indonesia to be able to run more effectively and efficiently, especially in terms of coordination and communication with foreign parties as investors, as well as maximizing the potential of human resources in the service and handling of Public Private Partnerships (PPP) project processes in Indonesia to improve infrastructure development faster. The strategic aspects of human resource management include several things, namely innovation for more effective and efficient human resources, long-term plans to achieve goals with good systematic, and reporting functions to run operational aspects to run well (Joshi, 2013).

In the era of globalization, there has been a change from the industrial world that previously was very dependent and needed human resources with physical strength and ability, becoming the need for human resources based on the ability of knowledge and expertise in their fields. Changes in this pattern of needs encourage changes in human resource management to be focused on the strategic level. (Senyucel, 2009) Strategy is defined in 4 concepts that explain it, there are: mission as the main goal or reason for the existence of the organization, objective which is the output of goals to be achieved within a deadline, vision is the expectations and desires of the organization that aspires to the organization. and policies that guide the performance of the organization (Senyucel, 2009). 
The strategy needed to increase the capacity of human resources in Public Private Partnerships (PPP) schemes in Indonesia if reviewed with the 4 concepts has a mission to improve the performance of infrastructure improvement projects in Indonesia with Public Private Partnerships (PPP) schemes. Then the objective or goal is to increase the capacity of human resources in Public Private Partnerships (PPP) institutions in Indonesia to be able to communicate well with investors. While the vision of the strategy is to strengthen human resources that understand Public Private Partnerships (PPP) policy schemes so that they are in line with the pace of globalization and digitalization, which are the aspects that dominate the performance of Public Private Partnerships (PPP) with foreign parties. Therefore, the policy for implementing a strategy to increase the capacity of human resources in the performance of Public Private Partnerships (PPP) in Indonesia needs to be implemented by the dealing agency as a guide to the progressive performance of its human resources.

Strategic planning needed to increase the capacity of human resources in Public Private Partnerships (PPP) scheme project institutions is to increase the capacity of human resources regarding Public Private Partnerships (PPP) schemes through training, seminars, and capacity building (Supancana, 2015). Another thing that is most important is increasing understanding of Public Private Partnerships (PPP) policies to existing human resources in implementing agencies to support clear and precise communication with investors. This is certainly a way of forming human resources with strategic planning management which is then directed at education and training on important aspects of coordination, communication, and understanding basic values to the detailed value of Public Private Partnerships (PPP) schemes. Early education is needed for new human resources as a provision for their knowledge of the Public Private Partnerships (PPP) scheme and the process behind the scheme. In addition, education about good and appropriate communication and coordination procedures needs to be given since the beginning of human resource recruitment. However, education and debriefing on Public Private Partnerships (PPP) schemes and appropriate communication and coordination models also need to be given to human resources that previously existed in the institution. It does not limit also to the implementation of seminars and sustainable capacity building in the hope of deepening the knowledge of human resources and inculcating the substance that is needed 
in their daily performance in the Public Private Partnerships (PPP) scheme implementation project.

Providing training is also needed in strategic plans to increase the capacity of human resources in Public Private Partnerships (PPP) scheme institutions. The training provided can be in the form of coordination training through capacity building that is carried out sustainably and sustainably. This is intended to familiarize human resources in Public Private Partnerships (PPP) institutions in coordinating with organizations from other countries, as well as with other countries' governments that are partners of Indonesia's cooperation in Public Private Partnerships (PPP) schemes and as investors. The training will develop the potential of human resources towards international standards in terms of coordination. The method used is to apply a more effective and directed method of coordinating Public Private Partnerships (PPP) schemes in training, as well as familiarizing existing human resources to maintain alignment of coordination both vertically and horizontally in the Public Private Partnerships (PPP) scheme program. With international standard coordination, the Public Private Partnerships (PPP) program will run well. In this globalization era, Indonesia cannot walk alone towards infrastructure development, but rather the need for cooperation with other countries and positive interdependence to improve domestic project performance. Thus the smooth coordination is needed in establishing partnership projects with foreign parties. In addition, the importance of training and debriefing for communication also needs attention. This has an effect on the smooth performance of coordination carried out in the implementation of Public Private Partnerships (PPP) projects between Indonesian Public Private Partnerships (PPP) institutions and investors from other countries.

The implementation of the IUWASH project is still constrained in implementing effective and efficient performance between USAID and the Government of Indonesia to jointly develop the habit of improving sanitation and strengthening values in the community in order to implement the IUWASH in the second year with more leverage. The constraints faced are human resources that do not yet have parallel capacity and are in harmony with human resources at the IUWASH project body itself. So there needs to be an increase in the development of human resources in local governments in Indonesia so that it can balance the performance of IUWASH and be able to carry out projects effectively and 
efficiently. Capacity building and development carried out is a form of innovation in human resource management in local government agencies carried out by providing capacity building, education, and training so that the motivation and commitment of human resources in local government agencies to be able to work together in the IUWASH are aligned because they receive international standard training and education so that the capacity of their human resources can be more competitive and can support the use of technology and big data that is very instrumental in the continued development of the IUWASH project in this second period.

Facing the Industrial Revolution 4.0 era, Indonesian Public Private Partnerships (PPP) are also faced with information technology challenges that influence the dynamics of coordination and communication of Indonesian Public Private Partnerships (PPP) institutions with foreign investors. Thus, education, training, and development in Public Private Partnerships (PPP) human resources need to be improved for the development of Public Private Partnerships's (PPP's) sustainability in Indonesia. In addition, with increasing performance by following the development of the Industrial Revolution 4.0, Public Private Partnerships (PPP) collaboration can run more easily, effectively and efficiently. Communication that is organized as the influence of the entry of information technology within the Public Private Partnerships (PPP) framework will accelerate the coordination of the Public Private Partnerships (PPP) scheme work program that will be implemented jointly between Indonesia and investors from foreign countries.

\section{Conclusion}

In the era of globalization and internationalization, Public Private Partnerships (PPP) in Indonesia need to improve the performance of their employees to face the demands and pressures that exist as an effect of globalization and internationalization. Management of human resources is an important thing that must be considered in an effort to improve the effectiveness of Public Private Partnerships (PPP) performance in Indonesia. The main factor in human resource management that must be improved and improved in the face of globalization is the provision of strategic plans to increase human resource capacity in Public Private Partnerships (PPP). Problem analysis arises from lack of motivation and commitment of existing human resources. This is due to the lack of training and debriefing 
about international standardized technology coordination and communication models. Increasing and building motivation and commitment of employees aims to prepare employees to face the demands and pressures of globalization that hit PPP organizations, increase fighting power and willingness to learn and work, and the latter will impact on increasing the effectiveness of employee performance at Public Private Partnerships (PPP) in the dynamics of globalization.

Strategic planning needed to increase the capacity of human resources in Public Private Partnerships (PPP) scheme project institutions includes increasing the capacity of human resources on Public Private Partnerships (PPP) schemes through training and debriefing, seminars, and capacity building as the development of existing international standard human resource potential. Another most important thing is to increase understanding of Public Private Partnerships (PPP) policies to human resources in implementing agencies to support clear and precise communication and coordination with investors. This is certainly a way of forming human resources with strategic planning management which is then directed at education and training on important aspects of coordination, communication, and understanding basic values to the detailed value of Public Private Partnerships (PPP) schemes.

Another thing that is most important is increasing understanding of Public Private Partnerships (PPP) policies to existing human resources in implementing agencies to support clear and precise communication with investors. This is certainly a way of forming human resources with strategic planning management which is then directed at education and training on important aspects of coordination, communication, and understanding basic values to the detailed value of Public Private Partnerships (PPP) schemes. Early education is needed for new human resources as a provision for their knowledge of the Public Private Partnerships (PPP) scheme and the process behind the scheme. In addition, education about good and appropriate communication and coordination procedures needs to be given since the beginning of human resource recruitment. However, education and debriefing on Public Private Partnerships (PPP) schemes and appropriate communication and coordination models also need to be given to human resources that previously existed in the institution. It is not limited to the implementation of seminars and sustainable capacity building in the hope of deepening the knowledge of human resources and inculcating the substance that is 
needed in their daily performance in the Public Private Partnerships (PPP) scheme implementation project.

The implementation of the Indonesia Urban Water, Sanitation and Hygiene (IUWASH) project is still constrained in implementing effective and efficient performance between USAID and the Government of Indonesia to jointly develop the habit of improving sanitation and strengthening values in the community in order to implement the Indonesia Urban program Water, Sanitation, and Hygiene (IUWASH) in the second year with more leverage. The constraints faced are human resources that do not yet have parallel capacity and are in harmony with human resources at the IUWASH project body itself. So there needs to be an increase in the development of human resources in local governments in Indonesia so that it can balance the performance of IUWASH and be able to carry out projects effectively and efficiently. Capacity building and development carried out is a form of innovation in human resource management in local government agencies carried out by providing capacity building, education, and training so that the motivation and commitment of human resources in local government agencies to be able to work together in the IUWASH are aligned because they receive international standard training and education so that the capacity of their human resources can be more competitive and can support the use of technology and big data that is very instrumental in the continued development of the IUWASH project in this second period.

IUWASH, Bappenas and other support institutions need to implement strategic plans as innovations in their ongoing development in terms of PPP scheme programs in Indonesia relating to cooperation with other state parties as well as foreign investors and institutions. The strategic plan to increase the potential of human resources through capacity building with international standard training and development is the main solution for PPP in facing the challenges of Industrial Revolution 4.0 where the development of information and communication technology is increasingly advanced and begins to dominate every aspect of government performance, in line with globalization that encourages governments to cooperate with the international community. International cooperation is now increasingly supported by internet use and big data as a means of facilitating performance among implementing actors. This requires PPP with human resources that are qualified, open and skilled in mastering industrial values in globalization and big data. 
This research has limitations on strategic planning needed to increase the capacity of human resources in PPP scheme project institutions in Indonesia in the face of the era of globalization and the Industrial Revolution 4.0. However, this study lacks insight into the impact of strategic planning applied to human resources at Indonesian PPP's in a long period of time and on specific PPP projects. In addition, this research should continue to identify further PPP and international cooperation between Indonesia and foreign investors in certain projects along with other constraints that may be caused by the human resources of the PPP. So that the handling of human resource management strategic planning is pursued as a way to improve the performance of Indonesian PPP's human resources in it will be more targeted.

\section{References}

\section{Books}

Joshi, M. (2013). Human Resource Management. Bookboon.Com.

Osborne, S. P. (2007). Public-Private Partnerships: Theory And Practice In International Perspective. London: Routledge.

Senyucel, Z. (2009). Managing The Human Resourece In The 21th Century. Ventus Publishing Aps.

Supancana, I. (2015). Laporan Pengkajian Hukum Tentang Penerapan Sistem Public Privat Partnership (Ppp) Dalam Proyek Pembangunan Energi Listrik. Jakarta: Badan Pembinaan Hukum Nasional Kementerian Hukum Dan Hak Asasi Manusia Ri.

Tyson, S. (1995). Human Resource Strategy: Towards A General Theory Of Human Resource Management. London: Pitman.

\section{Journal article}

Adnan, P. H. (2013). Kerjasama Pemerintah Dan Swasta Di Kota Surakarta. Politika: Jurnal Ilmu Politik, Volume 4, Nomor 1.

Prihantoro, A. (2012). Peningkatan Kinerja Sumber Daya Manusia Melalui Motivasi, Disiplin, Lingkungan Kerja, Dan Komitmen (Studi Kasus Madrasah Di Lingkungan Yayasan Salafiyah, Kajen, Margoyoso, Pati). Jurnal Unimus, Volume 8, Nomor 2 , 78-98. 
Qustolani, A. (2017). Pengaruh Kepuasan Kerja, Keadilan Prosedural Dan Kompensasi Terhadap Kinerja Karyawan. Jurnal Ilmiah Manajemen \& Akuntansi, Volume 4, Nomor 2 , 78-86.

Sjph. (2014). Strategic Planning. Scandinavian Journal Of Public Health, 42(14) , 106-112.

Yahiaoui, N., Anser, A., \& Lahouel, S. (2015). Human Resource Management And Public Organizations. Global Journal Of Human Resource Management , 1-12.

\section{Journal article with DOI}

Ahmad, M., Zakuan, N., Jusoh, A., Yusof, S., \& Takala, J. (2014). Moderating Effect Of Asean Free Trade Agreement Between Total Quality Management And Business Performance. Procedia - Social And Behavioral Sciences, 129, 244-249. Doi:10.1016/J.Sbspro.2014.03.673

Bennington, L., \& Habir, A. D. (2003). Human Resource Management In Indonesia. Human Resource Management Review, 13(3), 373-392. Doi:10.1016/S1053-4822(03)00041-X

Bovaird, T. (2004). Public-Private Partnerships: From Contested Concepts To Prevalent Practice. International Review Of Administrative Sciences, 70(2), 199-215. Doi:10.1177/0020852304044250

Capurro, D., Echeverry, A., Figueroa, R., \& Guiñez, S. (2017). Chile's National Center For Health Information Systems:A Public-Private Partnership To Foster Health Care Information Interoperability. International Medical Informatics Association (Imia), 245, 693-695. Doi:10.3233/978-1-61499-830-3-693

Chams, N. \& Blandon, J. G. (2019). On The Importance Of Sustainable Human Resource Management For The Adoption Of Sustainable Development Goals. Resources, Conservation \& Recycling, 141(1). 109-122

Chen, D., \& Su-Yen, W. (2016). Asean And The Aec. Asia Pacific Human Resource Management And Organisational Effectiveness, 17-37. Doi:10.1016/B978-0-08-100643-6.00002-6

Chien, H. (2016). Organisational Learning Through Public-Private Partnerships: A Human Resource Management Perspective. International Journal Of Public Policy, 12(3/4/5/6), 316. Doi:10.1504/Ijpp.2016.079738

Farazmand, A. (2012). Sound Governance: Engaging Citizens Through Collaborative Organizations. Public Organization Review, 12(3), 223-241. Doi:10.1007/S11115-012$0186-7$ 
Farazmand, A. (2013). Governance In The Age Of Globalization: Challenges And Opportunities For South And Southeast Asia. Public Organization Review, 13(4), 349363. Doi:10.1007/S11115-013-0249-4

Keers, B. B., \& Fenema, P. C. (2018). Managing Risks In Public-Private Partnership Formation Projects. International Journal Of Project Management, 36(6), 861-875. Doi:10.1016/J.Ijproman.2018.05.001

Kessey, E. K. (2017). The Dynamics Of Change: Exploring The Successes And Failures Of Business Process Re-Engineering In Kpbu Infrastructure Projects. Advances In PublicPrivate Partnerships, 98-111. Doi:10.1061/9780784480267.008

Kumari, J. (2016). Public-Private Partnerships In Education: An Analysis With Special Reference To Indian School Education System. International Journal Of Educational Development, 47, 47-53. Doi:10.1016/J.Ijedudev.2015.11.017

Riawan. (2016). Pengaruh Kualitas Sumber Daya Manusia Dan Kualitas Anggaran Terhadap Kinerja Keuangan Daerah Yang Dimoderasi Dengan Simda Pada Skpd Kabupaten Buton Utara. Jurnal Ekonomi Dan Ekonomi Studi Pembangunan, 8(1), 50-60. Doi:10.17977/Um002v8i12016p050

Vian, T. (2017). "It Keeps Us From Putting Drugs In Pockets": How A Public-Private Partnership For Hospital Management May Help Curb Corruption. The Permanente Journal, 21(16), 113th Ser. Doi:10.7812/Tpp/16-113

\section{Journal article retrieved from database without DOI}

Harsasto, P., \& Adnan, M. (2013). Kerjasama Pemerintah Dan Swasta Di Kota Surakarta (Studi Kerjasama Pemerintah Dan Swasta Di Surakarta 2005-2009). Politika: Jurnal Ilmu Politik, 4(1). Retrieved From

Https://Ejournal.Undip.Ac.Id/Index.Php/Politika/Article/Download/6066/5174

Kalangi, R. (2015). Pengembangan Sumber Daya Manusia Dan Kinerja Aparat Sipil Negara Di Kabupaten Kepulauan Sangihe Provinsi Sulawesi Utara. Jurnal Lppm Bidang Ekososbudkum, 2(1), 1-18. Retrieved From

Https://Ejournal.Unsrat.Ac.Id/Index.Php/Lppmekososbudkum/Article/View/9296.

Prihantoro, A. (2012). Peningkatan Kinerja Sumber Daya Manusia Melalui Motivasi, Disiplin, Lingkungan Kerja, Dan Komitmen (Studi Kasus Madrasah Di Lingkungan Yayasan Salafiyah, Kajen, Margoyoso, Pati). Jurnal Ilmiah Program Studi Manajemen 
Fakultas Ekonomi Universitas Muhammadiyah Semarang, 8(2), 78-86. Retrieved From Https://Jurnal.Unimus.Ac.Id/Index.Php/Vadded/Article/View/719.

Qustolani, A. (N.D.). Pengaruh Kepuasan Kerja, Keadilan Prosedural Dan Kompensasi Terhadap Kinerja Karyawan. Jurnal Ilmiah Manajemen \& Akuntansi, 4(2), 78-86. Retrieved From Jurnal.Unma.Ac.Id/Index.Php/Mk/Article/View/737.

Rifai, B. (2016). Kendala Implementasi Kerja Sama Pemerintah Swasta (Kps) Kelistrikan Dan Kebutuhan Perbaikan Kebijakan. Jurnal Ekonomi Dan Pembangunan,, 24(1), 51-66. Retrieved From Jurnalekonomi.Lipi.Go.Id/Index.Php/Jep/Article/View/159.

Selvia, M. (2014). Pengaruh Motivasi, Disiplin Kerja Dan Lingkungan Kerja Terhadap Kinerja Karyawan Pt. Inti General Yaja Steel Semarang. Jurnal Manajemen Sumber Daya Manusia,. Jurnal Manajemen Sumber Daya Manusia,. Retrieved From Mahasiswa.Dinus.Ac.Id/Docs/Skripsi/Jurnal/14306.Pdf.

\section{Website}

Usaid. (2016). Usaid Indonesia Urban Water Sanitation And Hygiene Final Report Executive Summary. Usaid. No. Aid-497-C-11-00001. 1-28

Usaid. (2017). Usaid Indonesia Urban Water Sanitation And Penyehatan Lingkungan Untuk Semua Quarterly Progress Report 3. Usaid. No. Aid-497-To-16-00003 1-58

Usaid. (2019). Berbenah Meraih Universal Access 2019, Praktik Cerdas Usaid Iuwash Regional Jawa Tengah.. Usaid.1-98 